\title{
Article \\ Age and Intrinsic Fitness Affect the Female Rotator Cuff Tendon Tissue
}

\author{
Manuela Thierbach ${ }^{1}$, Estelle Heyne ${ }^{2}\left(\mathbb{D}\right.$, Michael Schwarzer ${ }^{2}$, Lauren G. Koch ${ }^{3}{ }^{(}$, Steven L. Britton ${ }^{4}$ \\ and Britt Wildemann $1, *(\mathbb{D})$
}

1 Experimental Trauma Surgery, Department of Trauma, Hand and Reconstructive Surgery, Jena University Hospital, Friedrich Schiller University Jena, 07747 Jena, Germany; manuela.thierbach@med.uni-jena.de

2 Department of Cardiothoracic Surgery, Jena University Hospital, 07747 Jena, Germany; estelle.heyne@med.uni-jena.de (E.H.); michael.schwarzer@med.uni-jena.de (M.S.)

3 Department of Physiology and Pharmacology, The University of Toledo, Toledo, OH 43606, USA; lauren.koch2@utoledo.Edu

4 Department of Molecular and Integrative Physiology, University of Michigan, Ann Arbor, MI 48109, USA; brittons@med.umich.edu

* Correspondence: britt.wildemann@med.uni-jena.de

check for updates

Citation: Thierbach, M.; Heyne, E.; Schwarzer, M.; Koch, L.G.; Britton, S.L.; Wildemann, B. Age and Intrinsic Fitness Affect the Female Rotator Cuff Tendon Tissue. Biomedicines 2022, 10, 509. https://doi.org/ 10.3390/biomedicines10020509

Academic Editor: David T. Harris

Received: 24 January 2022

Accepted: 17 February 2022

Published: 21 February 2022

Publisher's Note: MDPI stays neutral with regard to jurisdictional claims in published maps and institutional affiliations.

Copyright: (C) 2022 by the authors. Licensee MDPI, Basel, Switzerland. This article is an open access article distributed under the terms and conditions of the Creative Commons Attribution (CC BY) license (https:// creativecommons.org/licenses/by/ $4.0 /)$.

\begin{abstract}
The risk of the development of tendon disorders or ruptures increases with age, but it is unclear whether intrinsic fitness during lifetime might also affect tendon properties. To investigate this, a contrasting rat model of high-capacity runners (HCR with high intrinsic fitness) and lowcapacity runners (LCR with low intrinsic fitness) was employed. Histological and molecular changes in rotator cuff (RC) tendons from 10 weeks old (young; HCR-10 and LCR-10) and 100 weeks old (old; HCR-100 and LCR-100) female rats were investigated. Age-dependent changes of RC tendons observed in HCR and LCR were increase of weight, decrease of tenocytes and RNA content, reduction of the wavy pattern of collagen and elastic fibers, repressed expression of Col1a1, Eln, Postn, Tnmd, Tgfb3 and Egr1 and reduction of the Col1:Col3 and Col1:Eln ratio. The LCR rats showed less physical activity, increased body weight, signs of metabolic disease and a reduced life expectancy. Their RC tendons revealed increased weight (more than age-dependent) and enlargement of the tenocyte nuclei (consistent with degenerative tendons). Low intrinsic fitness led to repressed expression of a further nine genes (Col3a1, Fbn1, Dcn, Tnc, Scx, Mkx, Bmp1, Tgfb1, Esr1) as well as the rise of the Col1:Col3 and Col1:Eln ratios (related to the lesser expression of Col3a1 and Eln). The intrinsic fitness influences the female RC tendons at least as much as age. Lower intrinsic fitness accelerates aging of $\mathrm{RC}$ tendons and leads to further impairment; this could result in decreased healing potential and elasticity and increased stiffness.
\end{abstract}

Keywords: tendon; high-capacity runners (HCR); low-capacity runners (LCR); rotator cuff; histology; gene expression; aging

\section{Introduction}

Tendons are elastic structures connecting bone and muscle and are essential for joint movement. Pathological alterations of tendon tissue are called tendinopathy and are associated with decreased tendon function and lead to pain and restricted mobility of the joints. Although the research on tendinopathies has increased within recent decades, the etiology is not fully understood. Tendinopathy of the rotator cuff (RC) is a common musculoskeletal disorder, and incidence increases with age. A systematic review showed that the prevalence of RC diseases in asymptomatic patients younger than 20 years is $7 \%$, while it increase to $56 \%$ in patients 80 years and older [1]. This age-related increase in RC diseases was also found in overall prevalence and in symptomatic patients. Furthermore, treatment of tendinopathies is not fully satisfactory due to a high failure rate. Healing of rotator cuff 
tears is reported to have a failure rate of $13 \%$ and factors affecting the healing are for example age, diabetes, hypertension, tear size and fatty infiltration [2]. The analysis of human rotator cuff tissue showed a significant decrease in cell biological characteristics and the expression and synthesis of the extracellular matrix protein collagen 1 as well as an altered expression of matrix-degrading enzymes in patients over 65 years of age [3,4]. However, the availability of human tissue is limited, and patients often suffer from other comorbidities that might affect the tissue. To closely investigate tendons, animal models are frequently used. Models for rotator cuff repair have been established, ranging from large to small animals such as rats that show anatomical features comparable to the human anatomy [5]. Use of animal models has experimental advantages, such as the collection of larger amounts of dissected tissue and not only biopsy samples, determined age, and good characterization, without or with defined comorbidities. A very interesting and unique animal model is the high- and low-exercise-capacity rats [6]. Two distinct rat lines were selectively bred from a genetically heterogeneous rat population: high-capacity runners (HCR) and low-capacity runners (LCR). After several generations, the rat lines differ significantly in their intrinsic (non-trained) maximal treadmill-running capacity and overall fitness. The HCR are healthy rats with high intrinsic fitness, while the LCR are sickly rats with low intrinsic fitness and a significantly reduced life expectancy [7]; LCR rats die at a median age of 24 months, whereas the HCR rats have a median lifespan around 35 months. The LCR showed an increase of cardiovascular risk factors and the development of a metabolic syndrome after 11 generations of selection [8]. Whether RC tendon tissue is altered in these animals has not yet been investigated. Two studies from Dirks et al. investigated Achilles' tendon tissue from HCR and found no alterations after uphill running (combined with intratendinous collagenase injection) regarding histopathological changes $[9,10]$. Analyzing the tissues from HCR and LCR rats allows insights into changes in tendon biology regarding age in combination with metabolic fitness in genetically unmodified animals. We hypothesize that tendons of the rotator cuff show changes on the histological and molecular level with respect to animal age and intrinsic fitness.

\section{Materials and Methods}

\subsection{Animal Model}

Female high- and low-capacity runners (HCR, LCR) from generations 39 and 41 were used (young: offspring from generation 41; old: offspring from generation 39). The rats were housed under standard conditions with a temperature-controlled environment and $12 \mathrm{~h}$ light/dark cycle. They had unlimited access to food (Normal Chow: V1534 with $9 \mathrm{~kJ} \%$ fat, $24 \mathrm{~kJ} \%$ protein and $67 \mathrm{~kJ} \%$ carbohydrates) and drinking water. This animal model has been described in detail in a previous publication [7]. No exercise training was performed. To characterize the rats, body weight, tibia size and blood glucose values were investigated. The LCR compared to HCR and the old rats compared to young rats showed a significantly higher body weight. The tibia of old rats was significantly longer than that of young rats. In young HCR, the fasting glucose value was significantly lower than in young LCR and the glucose tolerance was significantly higher in old HCR than in old LCR.

Animals with an age of 10 and 100 weeks were sacrificed, and the rotator cuffs harvested for further histological and molecular analysis. In accordance with the $3 \mathrm{R}$ principles, the tissue was obtained from animals used in another experiment, which was approved by the local authorities (Thüringer Landesamt für Verbraucherschutz, permission number: 02-082/14, approval date: 14 November 2014). In this experiment, no treatment was performed that could have an impact on the tendon. In total, tissue from 28 rats was obtained. Animals were weighed and deep anesthesia was induced using thiopental (150 mg/kg bodyweight) before animals were sacrificed.

\subsection{Sample Collection}

The right and left rotator cuff from each rat was prepared. The left rotator cuffs (bone, tendons and muscle) were used for histological evaluation. The tissues were fixed in $4 \%$ 
paraformaldehyde and stored at $4{ }^{\circ} \mathrm{C}$ for $48 \mathrm{~h}$. From the right rotator cuff the supraspinatus and infraspinatus tendons were carefully dissected and the musculature and surrounding tissue were eliminated. The tendons were used for gene expression analysis. RNA isolation was performed after snap-freezing in liquid nitrogen and storage at $-80{ }^{\circ} \mathrm{C}$.

\subsection{Histology}

After washing in PBS, the left rotator cuffs were embedded in methyl methacrylate (Technovit 9100, Kulzer, Wehrheim, Germany). Thin sections (10 $\mu \mathrm{m})$ were cut with a microtome (Polycut S, Reichert-Jung Optische Werke AG, Wien, Austria). For histological staining, sections were deplastinated in 2-Methoxyethylacetate and rehydrated in a descending alcohol series finishing off with ethanol 50\%. Only sections showing the entire supraspinatus enthesis were stained. Hematoxylin Eosin (HE) staining was performed with Mayer's hemalum solution (Merck KGaA, Darmstadt, Germany) and Eosin G 0.1\% (Merck KGaA). For Movat Pentachrome staining (MP), sections were stained with alcian blue $1 \%$ (Merck KGaA) for $10 \mathrm{~min}$ at room temperature. Then, sections were washed in water for $5 \mathrm{~min}$ and treated with alkaline ethanol for $60 \mathrm{~min}$. After $10 \mathrm{~min}$ washing, cell nuclei and elastic fibers were stained with Weigert's Hematoxylin (Solution A and B 1:1, Waldeck GmbH \& Co. KG, Münster, Germany) followed by the staining of the cytoplasm with Brilliant-Crocein-Acid Fuchsine (Waldeck) for $12 \mathrm{~min}$. Sections were differentiated with acidic acid 0.5\%, pickled with Phosphotungstic acid 5\% (Carl Roth GmbH \& Co. KG, Karlsruhe, Germany) for 20 min and again differentiated with acidic acid $0.5 \%$. After dehydration with ethanol 100\%, collagen fibers were stained with Safron du Gatinais (Waldeck, German) in 100\% ethanol for $60 \mathrm{~min}$.

\subsection{Image Analysis}

The HE stained sections were digitalized with a slide scanner (Hamamatsu Photonics Europe GmbH Herrsching, Germany) and viewed with the NDP.view 2.7.52 software (Hamamatsu Photonics). The analysis was performed with ImageJ 1.52p software (Wayne Rasband, National Institute of Health, Bethesda, MD, USA). Two representative fields of $40 \times$ magnification from the first third (initiating with the enthesis) of each supraspinatus tendon were chosen. To contrast the surrounding tissue, the tenocyte nuclei were selected manually with the freehand tool. The following parameters were analyzed: number, area, perimeter, circularity, minor and major dimension of the nuclei.

\section{5. $q R T-P C R$}

Tendon samples stored at $-80^{\circ} \mathrm{C}$ were homogenized with TRIzol (Thermo Fisher Scientific, Waltham, MA, USA) using a T25 digital ULTRA-TURRAX (IKA, Staufen, Germany). Phase separation was performed using chloroform. The RNA was purified with the RNeasy Plus Mini Kit (Qiagen, Hilden, Germany) according to the manufacturer's instructions and afterwards quantified with the NanoDrop 2000c spectrophotometer (Thermo Fisher Scientific, Waltham, MA, USA). Exemplary analysis of RNA integrity was performed with the Agilent 2200 TapeStation system (Agilent technologies, Santa Clara, CA, USA) and revealed good RNA quality with only slight RNA degradation. cDNA synthesis of $100 \mathrm{ng}$ RNA template was performed with the qScript cDNA Supermix (Quanta Bioscience, Gaithersburg, MD, USA). qRT-PCR was performed with the SYBR ${ }^{\circledR}$ Green SuperMix (Quanta Biosciences) and a Rotor-Gene Q (Quiagen). All primer sequences except the scleraxis primer (ordered at Qiagen, Cat No.: QT01596028) were designed using Primer-3- and NetPrimer-software (PREMIER Biosoft International, San Francisco, CA, USA) and produced by TIB Molbiol, Berlin, Germany (sequences are shown in Table 1). The 18s rRNA was chosen as housekeeping gene because it was most constant compared to hypoxanthine phosphoribosyl transferase (Hprt) and Glycerinaldehyd-3-phosphat-Dehydrogenase (Gapdh). All primers were tested for amplification efficiency and the $\Delta \mathrm{C}$ t method with efficiency correction was used to calculate the relative gene expression to the reference gene $18 \mathrm{~S}$ rRNA. The 
normalized expression was calculated using the following efficiency corrected equation according to Simon [11]:

$$
\mathrm{NE}=\frac{(\text { Primer efficiency }}{\text { Reference })^{\mathrm{C}_{\mathrm{qReference}}}}
$$

Table 1. qRT-PCR primer.

\begin{tabular}{|c|c|c|c|}
\hline Gene & $\begin{array}{l}\text { Accession } \\
\text { Number }\end{array}$ & Primer Sequence & $\begin{array}{l}\text { Amplicon Size } \\
\text { (bp) }\end{array}$ \\
\hline $18 S$ rRNA & NM_213557.1 & $\begin{array}{l}\text { forward: } 5^{\prime} \text { tgtggtgttgaggaaagcag } 3^{\prime} \\
\text { reverse: } 5^{\prime} \text { cctctatgggctcggatttt } 3^{\prime}\end{array}$ & 240 \\
\hline$A r$ & NM_012502.1 & $\begin{array}{l}\text { forward: } 5^{\prime} \text { tatcccagtccagttgtgtta } 3^{\prime} \\
\text { reverse: } 5^{\prime} \text { ccacagatcaggcaggtcttc } 3^{\prime}\end{array}$ & 152 \\
\hline$B g n$ & NM_017087.1 & $\begin{array}{l}\text { forward: } 5^{\prime} \text { gattgagaatgggagcctga } 3^{\prime} \\
\text { reverse: } 5^{\prime} \text { ccttggtgatgttgttggag } 3^{\prime}\end{array}$ & 143 \\
\hline Bmp1 & NM_031323.1 & $\begin{array}{l}\text { forward: } 5^{\prime} \text { caattaccccgacgattacc } 3^{\prime} \\
\text { reverse: } 5^{\prime} \text { tacccacaatatcgcccaat } 3^{\prime}\end{array}$ & 189 \\
\hline Col1a1 & NM_053304.1 & $\begin{array}{l}\text { forward: } 5^{\prime} \text { tgactggaagagcggagagt } 3^{\prime} \\
\text { reverse: } 5^{\prime} \text { gatagcgacatcggcaggat } 3^{\prime}\end{array}$ & 250 \\
\hline Col3a1 & NM_032085.1 & $\begin{array}{l}\text { forward: } 5^{\prime} \text { tgggatccaatgagggaga } 3^{\prime} \\
\text { reverse: } 5^{\prime} \text { tcatggccttgcgtgttt3 }\end{array}$ & 135 \\
\hline Dcn & NM_024129.1 & $\begin{array}{c}\text { forward: } 5^{\prime} \text { gcagggaatgaagggtctc } 3^{\prime} \\
\text { reverse: } 5^{\prime} \text { tccacaacggtgatgctatt } 3^{\prime}\end{array}$ & 195 \\
\hline Egr1 & NM_012551 & $\begin{array}{l}\text { forward:5' cacctgaccacagagtcctttt3' } \\
\text { reverse: } 5^{\prime} \text { aaagtgttgccactgttggg } 3^{\prime}\end{array}$ & 152 \\
\hline Eln & NM_012722.1 & $\begin{array}{l}\text { forward: 5'gtgtcggtcttccaggtgta } 3^{\prime} \\
\text { reverse: 5'gaaccttggccttgactcct3' }\end{array}$ & 117 \\
\hline Esr1 & NM_012689.1 & $\begin{array}{l}\text { forward: } 5^{\prime} \text { gccttctacaggtccaattctga } 3^{\prime} \\
\text { reverse: } 5^{\prime} \text { acagcacagtagcgagtctcc } 3^{\prime}\end{array}$ & 119 \\
\hline Fbn1 & NM_031825.1 & $\begin{array}{l}\text { forward: 5'gtgtgaactgagcgcgaac } 3^{\prime} \\
\text { reverse: } 5^{\prime} \text { cactggccaccatcacagata } 3^{\prime}\end{array}$ & 288 \\
\hline$F n 1$ & NM_019143.2 & $\begin{array}{l}\text { forward: } 5^{\prime} \text { tcccacgatccgatgatgt } 3^{\prime} \\
\text { reverse: } 5^{\prime} \text { tccacacggtatccagtcac } 3^{\prime}\end{array}$ & 118 \\
\hline$M k x$ & XM_017600733.1 & $\begin{array}{c}\text { forward: 5'gctctaggctcgcagatgac3' } \\
\text { reverse: 5'gcgttgccetgaacatactt3' }\end{array}$ & 143 \\
\hline Postn & NM_001108550 & $\begin{array}{l}\text { forward: } 5^{\prime} \text { tagggtgtgagggagacagc } 3^{\prime} \\
\text { reverse: } 5^{\prime} \text { caggtccgtgaaagtggttt } 3^{\prime}\end{array}$ & 170 \\
\hline $\operatorname{Scx}$ & NM_001130508.1 & Qiagen (QT01596028) & \\
\hline$T g f b 1$ & NM_021578.2 & $\begin{array}{l}\text { forward: } 5^{\prime} \text { aactgtggagcaacacgtagaa } 3^{\prime} \\
\text { reverse: } 5^{\prime} \text { tattccgtctccttggttcag3 } 3^{\prime}\end{array}$ & 157 \\
\hline$T g f b 3$ & NM_013174.2 & $\begin{array}{l}\text { forward: 5'gagggtggaagccattagg } 3^{\prime} \\
\text { reverse: } 5^{\prime} \text { gcagactgccagttcattgtg } 3^{\prime}\end{array}$ & 256 \\
\hline Tnc & NM_053861.1 & $\begin{array}{l}\text { forward: 5'atgttccaaagagccagcaa3' } \\
\text { reverse: } 5 \text { 'aggctgtagttgaggcggta } 3^{\prime}\end{array}$ & 247 \\
\hline Tnmd & NM_022290.1 & $\begin{array}{l}\text { forward:5'ggcccgaggtatccaagaag } 3^{\prime} \\
\text { reverse: } 5^{\prime} \text { agatgccagtgtatccgttttt } 3^{\prime}\end{array}$ & 177 \\
\hline
\end{tabular}

In total, the expression of 18 genes was analyzed. For gene expression analysis seven samples per group (HCR-10, HCR-100, LCR-10, LCR-100) were investigated. 


\subsection{Statistics}

The data are given in the text or shown in dot blots. The effect of aging within HCR and LCR, and the effect of fitness in age-matched groups was compared. For multiple group comparison of the non-parametric data the Kruskal-Wallis test followed by Mann-Whitney and Bonferroni-Holm correction was performed (SPSS 26, IBM, Armonk, NY, USA). A $p$-value of $\leq 0.05$ was considered statistically significant.

\section{Results}

This study investigated the effect of age and intrinsic fitness on the histology and gene expression of rat rotator cuff tendons. Rats 10 weeks of age (HCR-10 and LCR-10) are comparable to young sexually mature adolescent humans, while rats 100 weeks of age (HCR-100 and LCR-100) correspond approximately to humans 60 years of age. However, this age correlation might be influenced by the rat strain and is not absolute.

Body weight was significantly higher in the less fit LCR rats compared to HCR rats and in old rats compared to young rats independent of the intrinsic fitness (Figure 1A). The RC tendon weight was also significantly different, with the lowest weight in HCR-10 and the highest in LCR-100 (Figure 1B). Calculating the ratio of the RC tendon weight to body weight (Figure 1C), LCR-10 had the most massive RC tendons in relation to body weight. In old rats, the RC tendon-weight-to-body-weight ratio was smaller compared to young rats due to increasing body weight with age. The RNA content per tendon was significantly lower in old compared to young rats (Figure 1D).
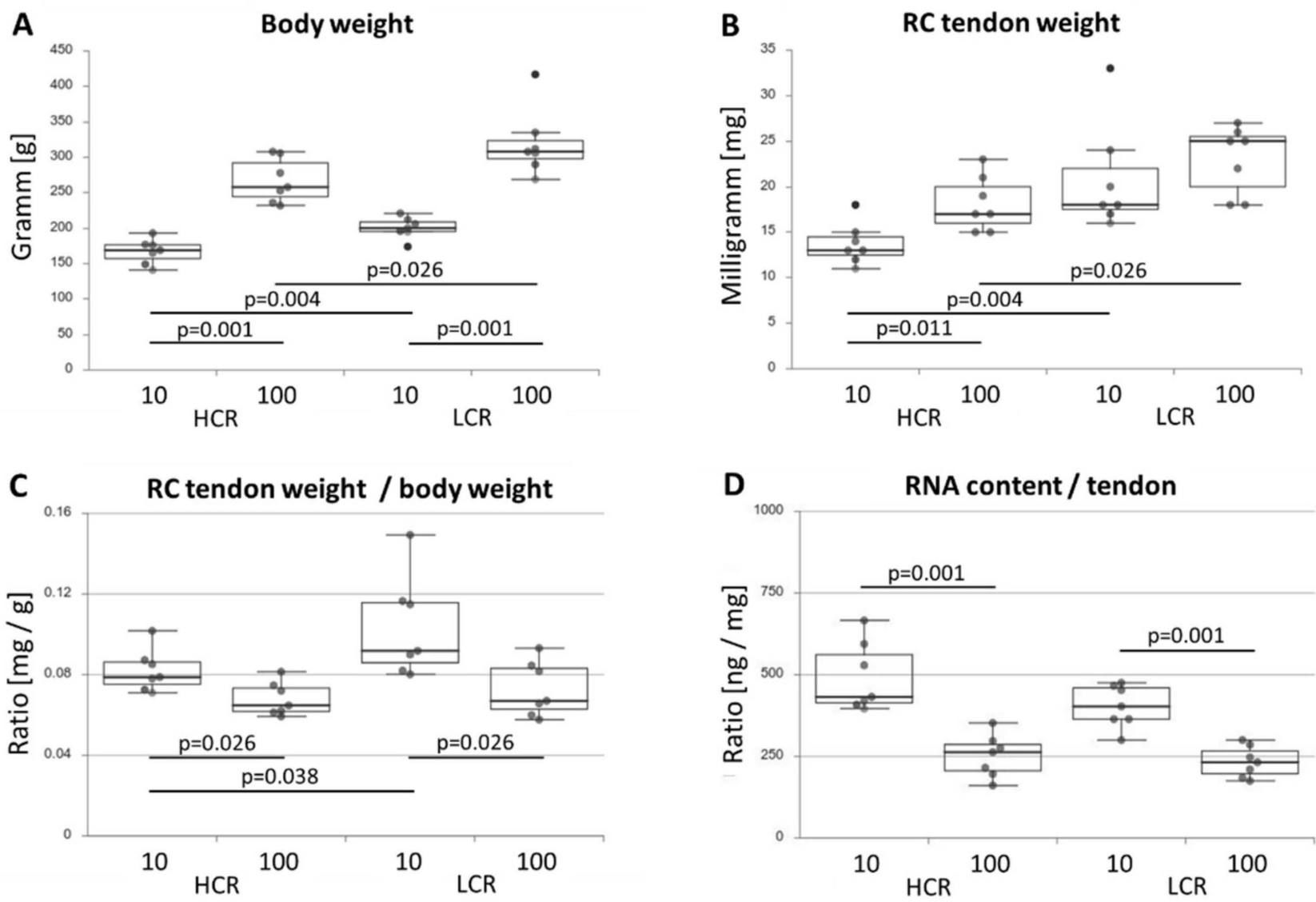

Figure 1. Body weight $[\mathrm{g}](\mathrm{A})$, weight of the $\mathrm{RC}$ tendon $[\mathrm{mg}](\mathbf{B})$, ratio of the $\mathrm{RC}$ tendon weight to body weight [mg/g] (C), and RNA content per tendon [ng/mg] (D) from HCR-10, HCR-100, LCR-10 and LCR-100. Significant differences (analyzed using the Kruskal-Wallis test followed by the Mann-Whitney U-test) are marked and the $p$-value displayed above. $n=7$ per group. 


\subsection{Histology of the Rotator Cuff}

The histological analysis of the first third (initiating with the enthesis) of the supraspinatus tendon showed intact supraspinatus tendons with collagen fiber bundles arranged in direction of mechanical load (Figure 2). In young HCR (Figure 2A) and LCR (Figure 2C) the supraspinatus tendon had a tightly packed structure. In the old rats, the tendon was less dense, and a decreased collagen matrix organization was observed, which was more pronounced in LCR-100 (Figure 2D) than in HCR-100 (Figure 2B).
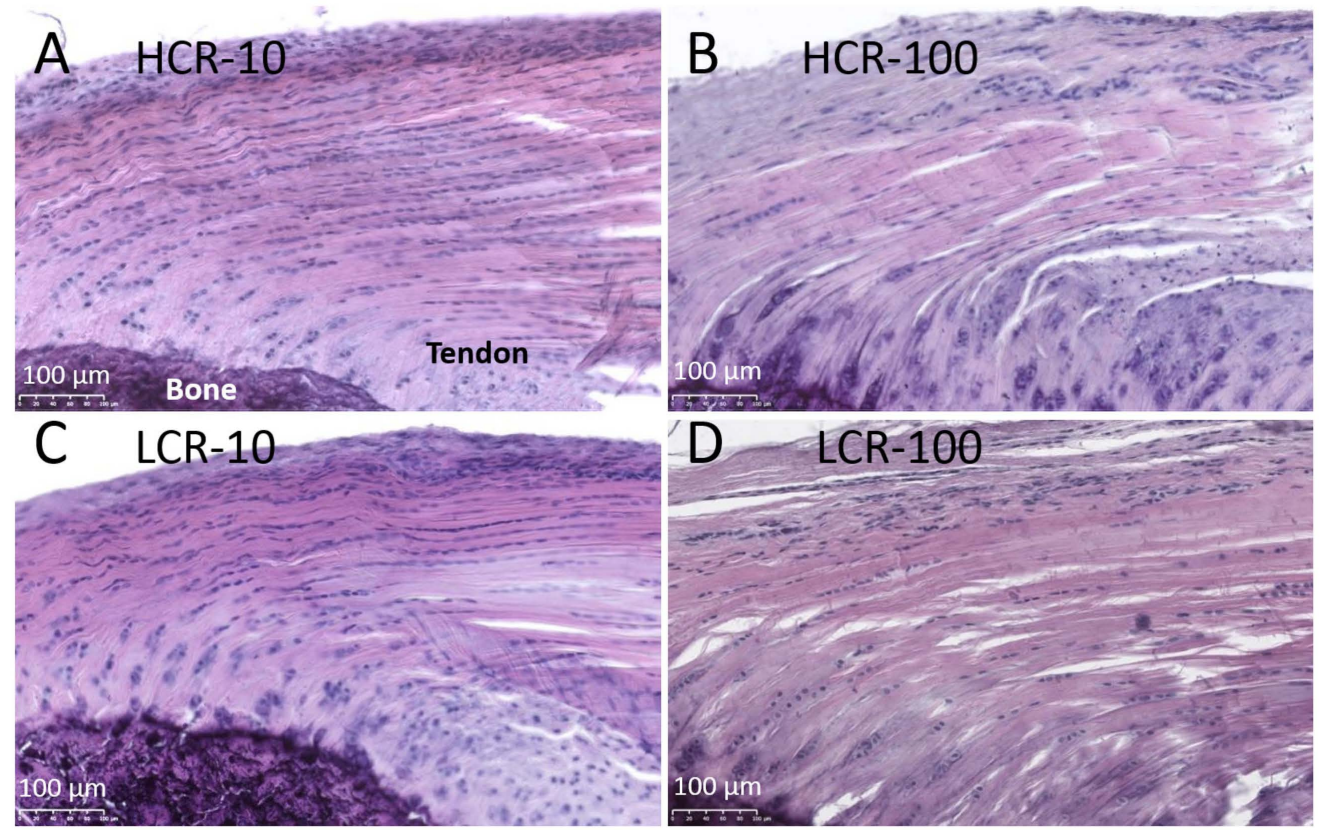

Figure 2. Histology of supraspinatus tendons from HCR-10 (A), HCR-100 (B), LCR-10 (C) and LCR-100 (D) using Hematoxylin Eosin (HE) staining. The tendons of the young rats showed a dense and aligned collagen structure with high cellularity. In the older rats, the structure was less dense with reduced number of cells. Scale bar: $100 \mu \mathrm{m}$. As marked in (A), the bone is always at the lower left corner.

The tenocytes were arranged in rows with longer rows in the young than in the old rats. In young LCR rats, the tenocytes nuclei were slightly rounder and larger than in the young HCR rats, whereas the old LCR rats showed significantly $(p=0.004)$ larger tenocyte nuclei than the old HCR rats (Table 2).

Table 2. Cell number and nucleus area of HCR and LCR.

\begin{tabular}{ccccc}
\hline Group & HCR-10 & HCR-100 & LCR-10 & LCR-100 \\
\hline Cell number & $149(113-189)$ & $60(43-61)^{\mathrm{a}}$ & $99(79-118)$ & $47(39-56)^{\mathrm{b}}$ \\
Area nucleus $\mu \mathrm{m}^{2}$ & $30.9(28.5-32.8)$ & $28.4(27.8-29.5)$ & $37.8(36.7-38.5)$ & $33.3(31.8-34.8)^{\mathrm{c}}$ \\
\hline
\end{tabular}

$\mathrm{a}^{\mathrm{a}}$ and ${ }^{\mathrm{b}}$ indicate significant differences in cell number in comparison to young animals of the same strain; ${ }^{\mathrm{c}}$ indicates significant differences to HCR-100. Data are given as median and interquartile range (Q1-Q3), $\mathrm{n}=7$ per group.

Using Movat Pentachrome staining (Figure 3) the collagens were stained yellow and the elastic fibers red. Elastic fibers support the recovery of the collagen wave-like pattern after stretching. The elastic fibers were distributed within tendons. The number of elastic fibers was higher in the young than in the old tendons, and the elastic fibers in the young tendons were wavier, similar to collagen fibers. 

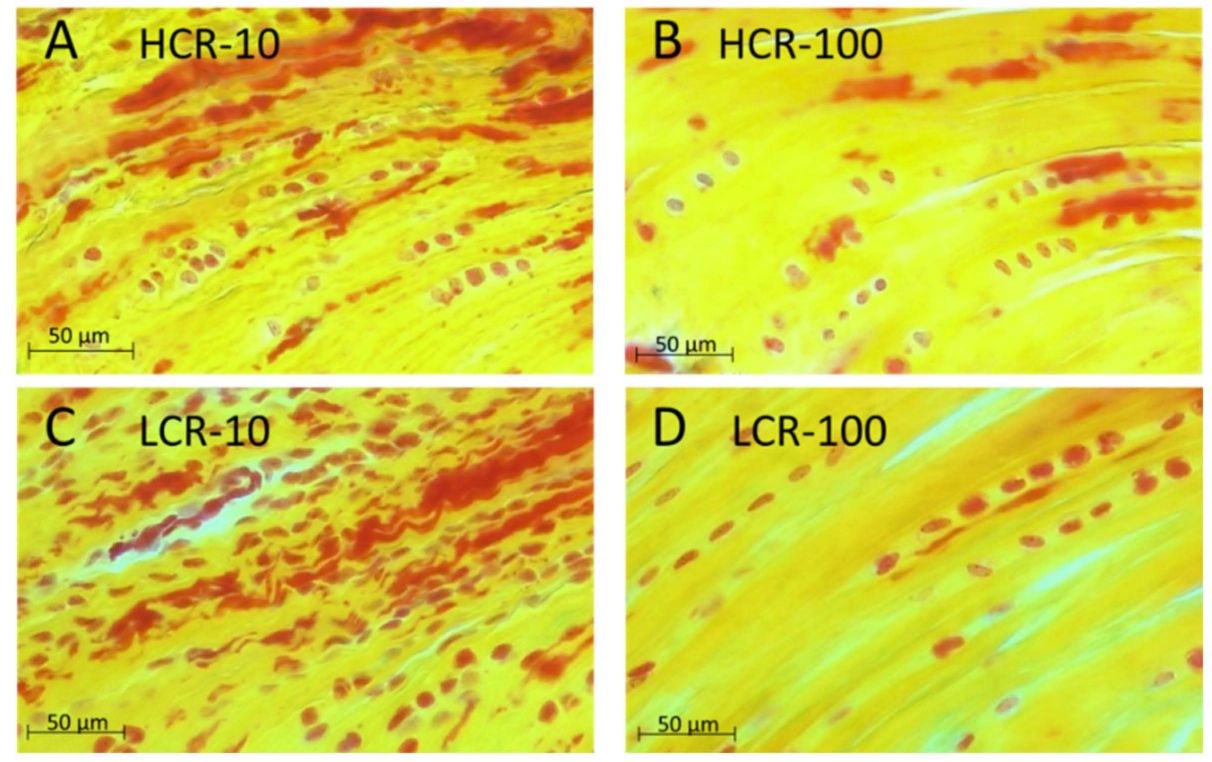

Figure 3. Histological staining of supraspinatus tendons of HCR-10 (A), HCR-100 (B), LCR-10 (C) and LCR-100 (D) using Movat Pentachrome (MP) staining. The number of elastic fibers and the wavy structure of the tendons of the young rats were reduced in the old tendons. Cell nuclei were stained in red; collagen in yellow and elastic fibers in red. Scale bar: $50 \mu \mathrm{m}$. The bone would be on the left side and the muscle on the right side of the tendon samples shown.

\subsection{Molecular Analysis of the Rotator Cuff Tendons}

The expression of several extracellular matrix genes, tendon-specific genes, transcription factors and growth factors is important for the maintenance and function of the tendon, and might be influenced by intrinsic fitness and age. The expression of genes important for formation and modelling of the extracellular matrix such as collagen 1a1 (Col1a1), collagen $3 a 1$ (Col3a1), decorin (Dcn), biglycan (Bgn), periostin (Postn), elastin (Eln), fibrillin 1 (Fbn1) and fibronectin $(F n)$ was investigated. In addition, the tenocyte markers tenomodulin $(T n m d)$, mohawk $(M k x)$, tenascin-C $(T n c)$, scleraxis $(S c x)$, the transcription factor early growth response 1 (Egr1), the cytokines transforming growth factor beta 1 (Tgfb1) and 3 (Tgfb3), the protease bone morphogenetic protein 1 (Bmp1) that cleaves the C-terminus of procollagen I, II and III, and the sex hormone receptors estrogen receptor alpha (Esr1) and androgen receptor $(A r)$ were analyzed. In the tendons of aged LCR, 12 genes were down-regulated, while in aged HCR only six genes were expressed lower in comparison to the young tendons (Figures 4-6). In young vs. old HCR these genes were Col1a1, Eln, Postn (Figure 4A,D,F), Tnmd, Egr1 (Figure 5C,D) and Tgfb3 (Figure 6C); in young vs. old LCR additionally down-regulated genes included Col3a1, Fbn1 (Figure 4B,E), Scx (Figure 5B), $B m p 1, T g f b 1$ and Esr1 (Figure 6A,B,D). Comparing HCR and LCR of the same age, the expression of only a few genes ( 3 genes at 10 weeks; 2 genes at 100 weeks) was significantly changed. In the tendons of 10 weeks old rats these were Fn1, Eln (Figure 4C,D) and Mkx (Figure 5A) while in the 100 weeks tendons these were Eln (Figure 4D) and Egr1 (Figure 5D). All genes were down-regulated in LCR compared to HCR. These data reveal that the age as well as the intrinsic fitness had an impact on the regulation of the expression of genes. This fact is seen very pronounced by the expression of Eln (Figure 4D). It was changed in all four comparisons (HCR-10/100, LCR-10/100, 10-HCR/LCR, 100-HCR/LCR), which means in age as well as intrinsic fitness-dependent manner. The expression of Dcn, Bgn, Tnc and $A r$ was not influenced neither by age (when comparing HCR-10/100 and LCR-10/100) nor by intrinsic fitness (when comparing 10-HCR/LCR and 100-HCR/LCR). 

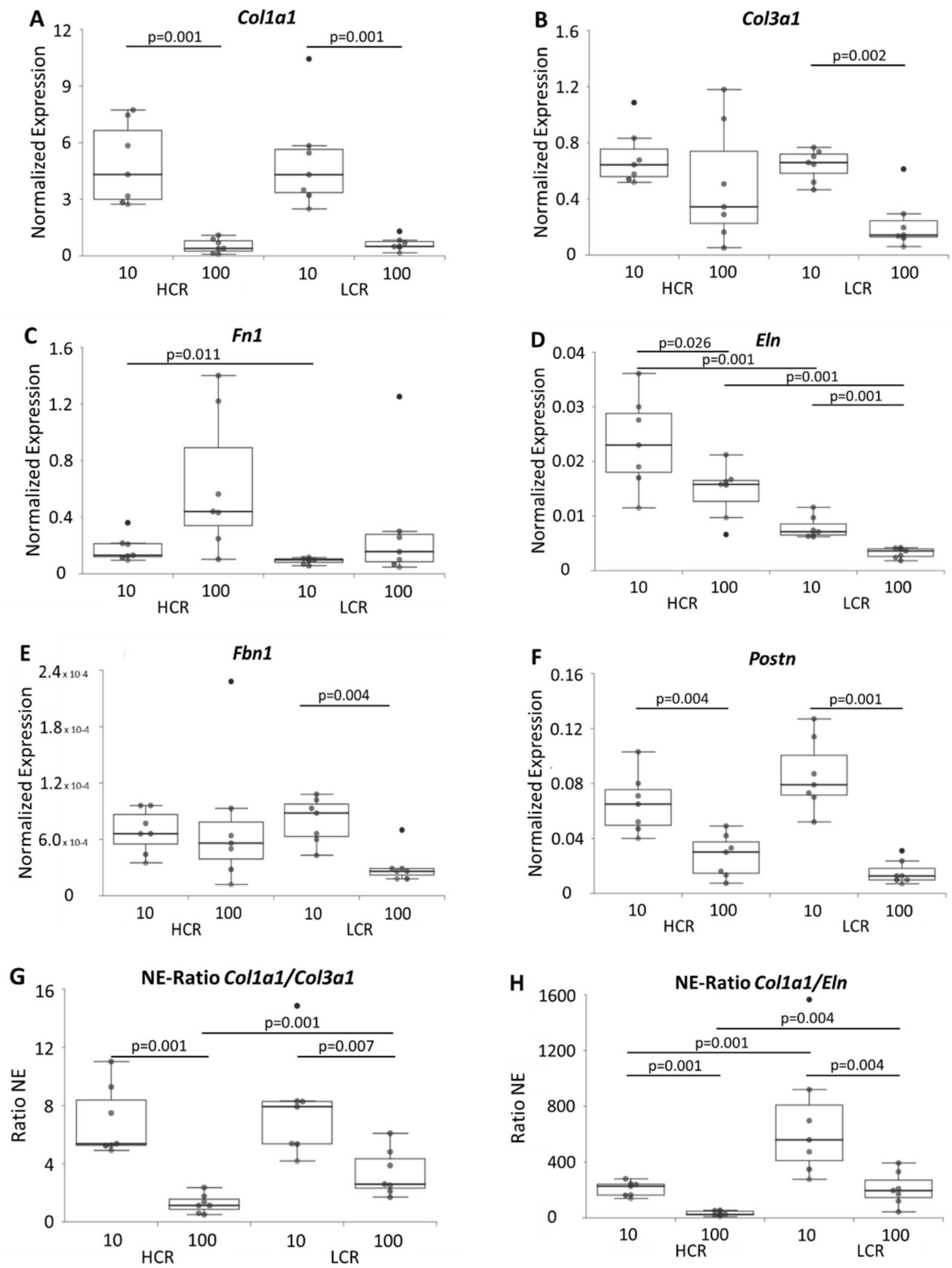

Figure 4. mRNA expression of ECM markers Col1a1 (A), Col3a1 (B), Fn1 (C), Eln (D), Fbn1 (E) and Postn (F) and Ratio of the NE Col1a1:Col3a1 (G) as well as Col1a1:Eln (H) in HCR-10, HCR-100, LCR-10 and LCR-100. Results are normalized to 18S rRNA and are shown as individual dot plots. Significant differences (analyzed using the Kruskal-Wallis test followed by the Mann-Whitney U-test and Bonferroni-Holm correction) are marked and the $p$-value displayed above. $n=7$ per group. 

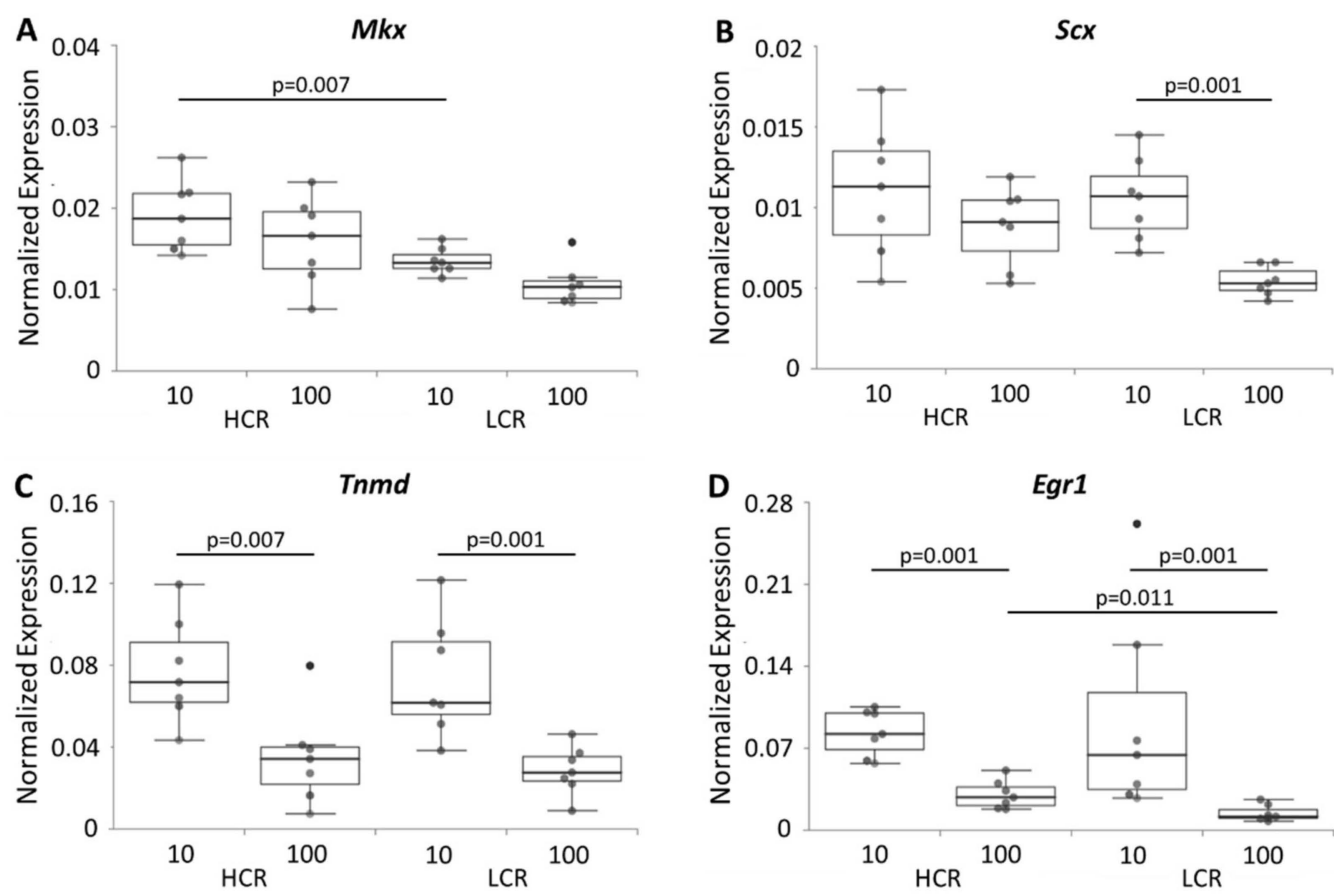

Figure 5. mRNA expression of the tenocyte markers $M k x(\mathbf{A}), S c x(\mathbf{B})$, Tnmd (C) and the transcription factor Egr1 (D). Results are normalized to $18 \mathrm{~S}$ rRNA and are shown as individual dot plots. Significant differences (analyzed using the Kruskal-Wallis test followed by the Mann-Whitney U-test and Bonferroni-Holm correction) are marked and the $p$-value displayed above. $n=7$ per group.
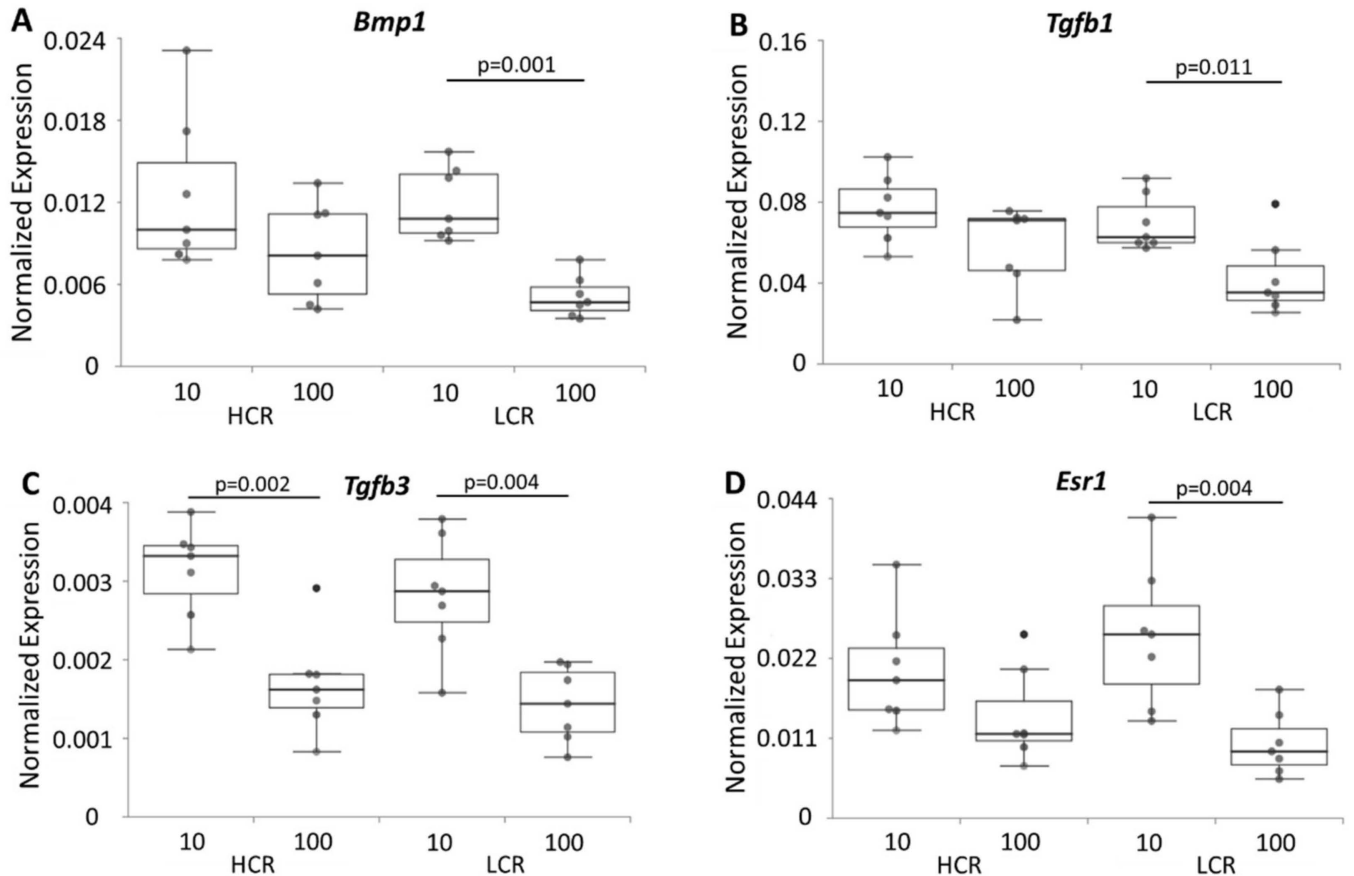

Figure 6. mRNA expression of the metalloprotease Bmp1 (A), the cytokines $T g f b 1$ (B), $T g f b 3$ (C) and the sex hormone receptor Esr1 (D). Results are normalized to 18S rRNA and are shown as individual dot plots. Significant differences (analyzed using the Kruskal-Wallis test followed by the Mann-Whitney U-test and Bonferroni-Holm correction) are marked and the $p$-value displayed above. $\mathrm{n}=7$ per group. 
The ratio of Col1:Col3 was significantly reduced by age, but increased in LCR-100 compared to HCR-100 (Figure 4G). The Col1:Eln ratio was also affected with a significant change due to age and higher intrinsic fitness (Figure $4 \mathrm{H}$ ).

In the next step, a special focus was set on the effect of low intrinsic fitness. To achieve this, HCR-10 were defined as fit rats and the influence of age (Figure 7A, relative gene expression in HCR-100) was compared with the combined influence of age and low intrinsic fitness (Figure 7B, relative gene expression in LCR-100). In the tendons of old HCR (influence of age; Figure 7A) the expression of six genes was significantly reduced; in old LCR (influence of age plus low intrinsic fitness; Figure 7B) 15 genes were significantly reduced. This means age resulted in a down-regulation of gene expression while age paired with low intrinsic fitness resulted in a stronger down-regulation of gene expression. In HCR-100 tendons (Figure 7A) the expression of Col1a1 was lower than one third (shown as horizontal 1/3 line) of the HCR-10 gene expression. In LCR-100 tendons (Figure 7B) the expression of Col1a1, Egr1, Eln, Postn, Col3a1 and Tnc showed such a strong reduction. In addition, especially Egr1, Eln, Col3a1, Tnc and Fbn-1 were strongly down-regulated in comparison to HCR-100; the vertical arrows mark reduction of gene expression for $\geq 60 \%$.

A

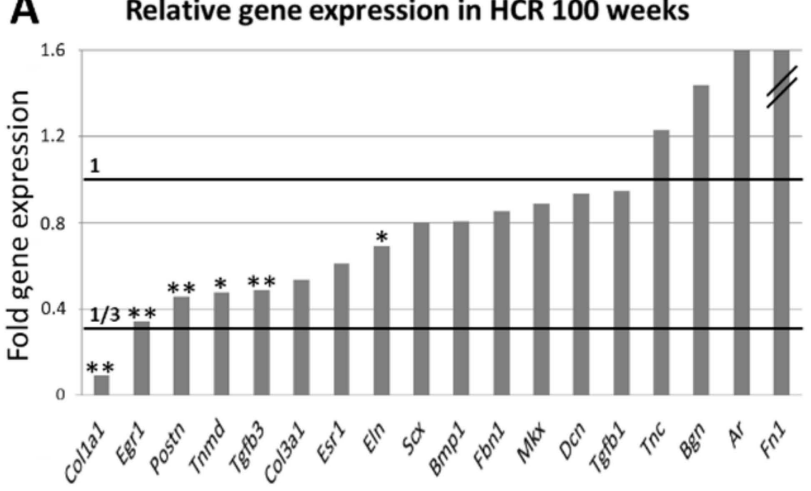

\section{B Relative gene expression in LCR 100 weeks}

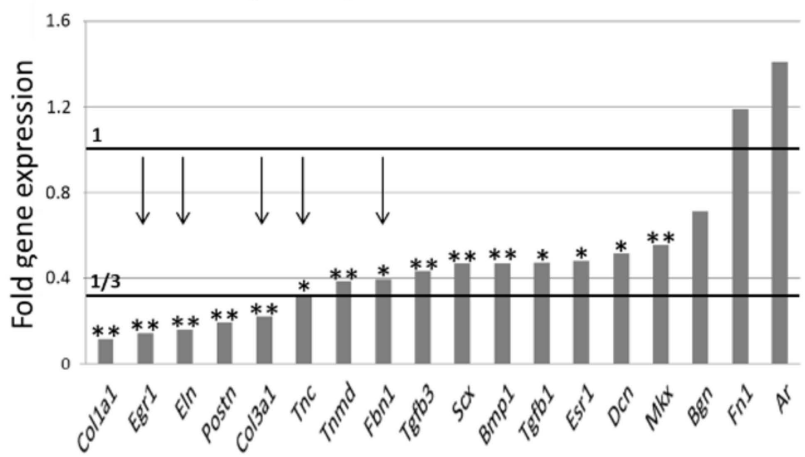

Figure 7. Effect of intrinsic fitness on gene expression. Relative gene expression of 18 genes in HCR-100 (A) and in LCR-100 (B) given as fold change to HCR-10 (horizontal line, mean value = 1). Significant differences (Mann-Whitney U-test) between HCR-10 and HCR-100 and between HCR-10 and LCR-100 are marked with * $(p \leq 0.05)$ or ${ }^{* *}(p \leq 0.005)$. The vertical arrows in (B) mark reduction in gene expression of $\geq 60 \%$ in comparison to (A).

\section{Discussion}

Tendinopathy seems to be a multifactorial process significantly influenced by age and health status. The present study aimed at investigating the histological and molecular characteristics of the RC tendons of young vs. old as well as fit HCR vs. less fit LCR rats. Histological and molecular alteration were analyzed and compared between HCR and LCR to better understand possible reasons for the development of degenerative tendon pathologies. Our results indicated that age as well as fitness influenced the female RC tendons strongly.

\subsection{The Effect of Age on the Rat Rotator Cuff Tendon}

Old rats, independent of their intrinsic fitness, presented with significantly higher body weight and $\mathrm{RC}$ tendon weight than the young rats. The histological investigations also showed differences in the supraspinatus tendons between young and old rats. More than twice as many tenocytes were counted in tendons of young rats compared to old. Tenocytes are the major cell type in tendons and the reduction of the cell number with age was also reported by Ippolito et al. [12] for rabbit Achilles' tendons and by Dunkman et al. [13] for mice patellar tendons. The decreased cell number (about two-fold) could explain the significant reduction of the RNA content per tendon in the old rats (also about two-fold). Furthermore, the tendons of young rats exhibited a wavy or crimped pattern of collagen and elastic fibers, which was reduced in the old rats. The structural properties may 
play an important role in tendon elasticity and response to fatigue loading [14]. This might indicate that the supraspinatus tendons of old rats were less elastic and stiffer compared to young rats.

Additionally, there was an age-related repression of gene expression in both HCR and LCR. In young vs. old RC tendons Col1a1, Eln, Postn, Tnmd, Tgfb3 and Egr1 were down-regulated. This can be seen as an effect of normal (natural) aging. Collagen type I is the major structural component of the tendon, and its age-dependent repression was also reported for rat [15], horse [16] and for human tendons [17]. ELN is the core protein of elastic fibers and ensures elastic stretching and recoiling of tissue, cooperating with collagen for tensile resistance [18]. For horse tendons, Godinho et al. [19] reported an age-dependent ELN reduction. The age-dependent repression of Colla1 and Eln was confirmed with the histological result showing a loss of crimped pattern of collagen and elastic fibers in the supraspinatus tendon of old rats. POSTN is a secreted ECM protein involved in the regulation of cell-cell and cell-matrix interactions [20] and promotes tendon regeneration. It interacts with collagen type I and plays an important role in collagen fibrillogenesis [21]. In accordance with our results, Wang et al. [22] found that Postn was expressed at high levels in early rat tendon development and was reduced in mature tendons. TNMD is a tendonspecific marker known to be important for tendon maturation with key implications for the residing tendon stem/progenitor cells. An age-dependent down-regulation of Tnmd was described in horse tendons [16] but also in mice intervertebral discs and has been postulated as a risk factor for age-related degeneration [23]. Regarding the healing of rotator cuff tears it has already been shown that the sustained delivery of TGFB3 accelerated the healing process [24] and in mouse Achilles' tendons canonical TGF $\beta$ signaling has a functional role in tendon regeneration [25]. EGR1 is a transcription factor and important for embryonic and postnatal tendon development [26]. It induces tenogenic differentiation of tendon stem cells and promotes rabbit rotator cuff repair [27]. Egr1 is regulated by mechanical loading and a lack of EGR1 is associated with weaker tendon formation [28]. Thus, age influences the expression of various genes important for formation, maturation, maintenance and regeneration of the tendon extracellular matrix.

The ratio of Col1:Col3 and of Col1:Eln was significantly reduced by age in HCR as well as in LCR tendons. This was caused by the strong age-dependent down-regulation of the Col1a1 expression, which was more pronounced than the down-regulation of Col3a1 and $E l n$, respectively. Collagen type I is the predominant collagen type in tendon tissues, followed by collagen type III. Alterations affect the formation of collagen fibrils and the ECM, which globally impairs tendon structure, biomechanics and tendon repair and may contribute to pathogenesis of tendinopathy. Change of the ratio of Col1a1:Eln has been considered to be a sign of developing lumbar spinal stenosis in elder patients [29] and the COL:ELN ratio was described as an accurate predictor of arterial burst pressure [30].

The repression of the expression of the investigated genes and the histological changes described above may be associated with increased risk of tendon injury with aging.

\subsection{The Effect of Low Intrinsic Fitness on the Rat Rotator Cuff Tendon}

HCR and LCR rats are a well-characterized animal model, showing significant differences in the intrinsic running capacity/fitness [7]. The low intrinsic fitness associated changes of the LCR tendons, which were found in the present study, may be explained by several comorbidities associated with this model. The body weight of the LCR-10 and LCR-100 was significantly higher compared to the HCR-10 and HCR-100, indicating an obese phenotype of LCR, which is a clinical picture of the metabolic syndrome. The RC weight was significantly higher in LCR-10 and LCR-100 than in HCR-10 and HCR-100. Correlating tendon weight to body weight, LCR-10 showed higher values than HCR-10 and LCR-100. Taking these data together, LCR developed massive RC tendons early in life, but not HCR. This increase in tendon thickness is in line with human data. Akturk et al. [31] reported that the supraspinatus tendons in diabetic patients become thickened. 
In a diabetic rat model, it was observed that the thickness of the Achilles' tendons was significantly increased in the diabetic animals in comparison to the control group [32].

The histological investigations showed an increased nuclear size and rounding of the nuclei especially in old LCR, which is consistent with degenerative tendons and was also observed in diabetic mouse Achilles' tendons [33]. Furthermore, the observed increased interfibrillar spaces were also reported for Achilles' tendons of diabetic patients [34]. All these results supported differences between HCR and LCR RC tendons and were confirmed by molecular analysis. To differentiate the pure effect of low intrinsic fitness, the gene expression in RC tendons of HCR-10 vs. HCR-100 was compared with HCR-10 vs. LCR-100. In HCR-10 vs. HCR-100 Col1a1, Eln, Postn, Tnmd, Tgfb3 and Egr1 were down-regulated and this was defined as an effect of normal aging (see Section 4.1 above).

In HCR-10 vs. LCR-100, these six and a further nine genes (Col3a1, Fbn1, Scx, Mkx, Bmp1, Tgfb1, Dcn, Tnc, Esr1) were down-regulated. In addition, the repression of Col3a1, Eln, Fbn1, Egr1 and Tnc was very strong in LCR-100; by more than $60 \%$ in comparison to HCR-100.

Collagen type 3 is the "repair-collagen" [35], and ELN and FBN1 are the major components of the elastic fibers. The tenocyte markers MKX [36], SCX [37] and EGR1 are crucial transcription factors associated with tendon development and repair, may alter homeostasis and affect the maintenance and remodeling of tendons by regulating the expression of downstream tendon-related genes and matrix molecule genes. The procollagen C-proteinase BMP1 cleaves the C-terminus of procollagen I, II and III and induces accumulation of extracellular matrix [38]. TGFB1 has important and various effects on the metabolism of ECM components in tendons [39,40]. Additionally, Dcn and Tnc were repressed; both have essential roles in tissue homeostasis and function. DCN is necessary for maintaining collagen fibril structure and fiber [41-43]. TNC is a non-adhesive glycoprotein that has been described as a major player in the adaptation of tendon cells to mechanical loadings [44] and is important for the establishment and maintenance of the fibrocartilagenous regions of tendons [45]. Finally, expression of Esr1 was repressed in LCR-100 in comparison to HCR-100 and its down-regulation may reflect the metabolic syndrome in LCR-100. It was shown that whole-body deletion of ESR1 in mice affects multiple tissues resulting in hyperinsulinemia, insulin resistance $[46,47]$, impaired oxidative metabolism [48], increased inflammation [48], impaired glucose tolerance [46,47,49,50] and decreased physical activity [51] as well as increased fat and body mass [48,52,53]. Thus, ubiquitous knockout of Esr1 results in a phenotype similar to that of metabolic syndrome $[48,54,55]$.

Low intrinsic fitness resulted in a (partially strong) down-regulation of many genes in $\mathrm{RC}$ tendons, which are important for tendon development, repair and function, maintenance and remodeling.

These results indicate low intrinsic fitness:

- influences the RC tendons at least as much as age;

- may result in pronounced changes in the expression of ECM proteins, tendon-related genes and transcription factors that are essential for tendon formation, maturation, maintenance, remodeling, repair and function;

- $\quad$ affects especially aged tendons (the tendons of old LCR rats were more affected than the tendons of young LCR);

- may accelerate unhealthy aging with the pathogenesis of tendinopathy via repression of gene expression.

In a 2021 published study, the histological and molecular alteration in the Achilles tendon of this rat model were investigated [56]. An age-dependent effect was seen with down-regulation of ECM and inflammatory factors in the old rats. However, differences between the HCR and LCR rats were not detected in the Achilles tendon. This contrasts with the present study, which showed strain-dependent differences in the rotator cuff tendons. An explanation could be the functional and anatomical differences of the investigated tendons. 


\subsection{Limitations}

The results of the presented study showed significant effects of aging and low intrinsic fitness on the histological appearance of the rotator cuff tendon and the expression of genes related to the ECM and tendon markers. The changes could affect the mechanical properties of the tissue and therefore analysis of the mechanical characteristics would have been interesting. To meet the 3R principles for more ethical animal use, we obtained the rotator cuff tissue from animals used in another experiment that did not affect tendon tissue. However, the number of animals available was therefore restricted and we had to prioritize the methods used to analyze the tissue. Therefore, no tissue was available for the mechanical testing of tendon properties.

\section{Conclusions}

The present findings demonstrate that a reduced cellularity and RNA content, reduction of the wavy pattern of collagen and elastic fibers, as well as reduced expression of genes related to ECM and tenocytes and the reduction of the Col1:Col3 and Col1:Eln ratio, are associated with the aging of female RC tendons. Those features indicate a reduced metabolic activity and decreased tendon function and could be the reason for tendinopathies.

Low intrinsic fitness additionally leads to increased RC tendon weight, enlarged tenocyte nuclei (consistent with degenerative tendons), and lower expression of genes important for tendon tissue. Intrinsic fitness affects the RC tendons at least as much as aging, probably more, as demonstrated by more regulated genes. The results indicate a faster aging of the tendons of LCR rats with a more pronounced predisposition for degenerative diseases.

Some of the low intrinsic fitness-dependent features appear already in the young LCR: increased weight of the RC tendons, repressed expression of $F n 1, E l n, M k x$ and rise of the Col1:Eln ratio.

Thus, low intrinsic fitness not only accelerates aging but may also be an independent risk for developing tendon diseases.

Author Contributions: Conceptualization, M.T. and B.W.; methodology, M.T.; validation, M.T., B.W.; formal analysis, M.T.; investigation, M.T.; resources (animal data and tissue), E.H. and M.S.; development of animal model, L.G.K. and S.L.B.; data curation, M.T.; writing-original draft preparation, M.T. and B.W.; writing-review and editing, M.T., E.H., M.S., L.G.K., S.L.B. and B.W.; visualization, M.T.; supervision, B.W.; project administration, M.T.; All authors have read and agreed to the published version of the manuscript.

Funding: This study was supported by internal funding of the UKJ. The APC was funded by the German Research Foundation and the Open Access Publication Fund of the Thueringer Universitaets- and Landesbibliothek Jena Project-Nr. 433052568. LCR-HCR rat model is funded by NIH grant P40OD021331.

Institutional Review Board Statement: In accordance with the 3R principals, the tissue was obtained from animals used in another experiment, which was approved by the local authorities (Thüringer Landesamt für Verbraucherschutz, permission number: 02-082/14).

Informed Consent Statement: Not applicable.

Data Availability Statement: The original data presented in the study are included in the article and queries can be directed to the corresponding author.

Animal Model Availability: The LCR-HCR rats are maintained as an animal model resource at The University of Toledo, Toledo, OH. Contact LGK (Lauren.Koch2@UToledo.Edu) or SLB (brittons@umich.edu) for information.

Acknowledgments: We thank Uta Dahmen, Janine Arlt and Ana Lucia Paz Hernandez from the Clinic for general, visceral and vascular surgery at Universitätsklinikum Jena for digitalization of the tissue sections. Waltraud Palm supported the PCR and histological analysis. We acknowledge support by the German Research Foundation and the Open Access Publication Fund of the Thueringer Universitaets- and Landesbibliothek Jena Project-Nr. 433052568. 
Conflicts of Interest: The authors declare no conflict of interest.

\section{References}

1. Teunis, T.; Lubberts, B.; Reilly, B.T.; Ring, D. A systematic review and pooled analysis of the prevalence of rotator cuff disease with increasing age. J. Shoulder Elbow Surg. 2014, 23, 1913-1921. [CrossRef]

2. Park, J.S.; Park, H.J.; Kim, S.H.; Oh, J.H. Prognostic factors affecting rotator cuff healing after arthroscopic repair in small to medium-sized tears. Am. J. Sports Med. 2015, 43, 2386-2392. [CrossRef] [PubMed]

3. Klatte-Schulz, F.; Aleyt, T.; Pauly, S.; Geissler, S.; Gerhardt, C.; Scheibel, M.; Wildemann, B. Do matrix metalloproteases and tissue inhibitors of metalloproteases in tenocytes of the rotator cuff differ with varying donor characteristics? Int. J. Mol. Sci. 2015, 16, 13141-13157. [CrossRef] [PubMed]

4. Klatte-Schulz, F.; Pauly, S.; Scheibel, M.; Greiner, S.; Gerhardt, C.; Schmidmaier, G.; Wildemann, B. Influence of age on the cell biological characteristics and the stimulation potential of male human tenocyte-like cells. Eur. Cell Mater. 2012, $24,74-89$. [CrossRef] [PubMed]

5. Lebaschi, A.; Deng, X.H.; Zong, J.; Cong, G.T.; Carballo, C.B.; Album, Z.M.; Camp, C.; Rodeo, S.A. Animal models for rotator cuff repair. Ann. N. Y. Acad. Sci. 2016, 1383, 43-57. [CrossRef]

6. Koch, L.G.; Britton, S.L. Artificial selection for intrinsic aerobic endurance running capacity in rats. Physiol. Genom. 2001, 5, 45-52. [CrossRef]

7. Koch, L.G.; Britton, S.L.; Wisløff, U. A rat model system to study complex disease risks, fitness, aging, and longevity. Trends Cardiovasc. Med. 2012, 22, 29-34. [CrossRef]

8. Wisloff, U.; Najjar, S.M.; Ellingsen, O.; Haram, P.M.; Swoap, S.; Al-Share, Q.; Fernstrom, M.; Rezaei, K.; Lee, S.J.; Koch, L.G.; et al. Cardiovascular risk factors emerge after artificial selection for low aerobic capacity. Science 2005, 307, 418-420. [CrossRef]

9. Dirks, R.C.; Galley, M.R.; Childress, P.J.; Fearon, A.M.; Scott, A.; Koch, L.G.; Britton, S.L.; Warden, S.J. Uphill running does not exacerbate collagenase-induced pathological changes in the achilles tendon of rats selectively bred for high-capacity running. Connect. Tissue Res. 2013, 54, 386-393. [CrossRef]

10. Dirks, R.C.; Richard, J.S.; Fearon, A.M.; Scott, A.; Koch, L.G.; Britton, S.L.; Warden, S.J. Uphill treadmill running does not induce histopathological changes in the rat achilles tendon. BMC Musculoskelet. Disord. 2013, 14, 90. [CrossRef]

11. Simon, P. Q-Gene: Processing quantitative real-time RT-PCR data. Bioinformatics 2003, 19, 1439-1440. [CrossRef]

12. Ippolioto, E.; Natali, P.G.; Postacchini, F.; Accinni, L.; De Martino, C. Morphological, immunochemical, and biochemical study of rabbit achilles tendon at various ages. JBJS 1980, 62, 583-598. [CrossRef]

13. Dunkman, A.A.; Buckley, M.R.; Mienaltowski, M.J.; Adams, S.M.; Thomas, S.J.; Satchell, L.; Kumar, A.; Pathmanathan, L.; Beason, D.P.; Iozzo, R.V.; et al. Decorin Expression Is Important for Age-Related Changes in Tendon Structure and Mechanical Properties. Matrix Biol. 2013, 32, 3-13. [CrossRef] [PubMed]

14. Zuskov, A.; Freedman, B.R.; Gordon, J.A.; Sarver, J.J.; Buckley, M.R.; Soslowsky, L.J. Tendon Biomechanics and Crimp Properties Following Fatigue Loading Are Influenced by Tendon Type and Age in Mice. J. Orthop. Res. 2020, 38, 36-42. [CrossRef] [PubMed]

15. Laitinen, $\mathrm{O}$. The metabolism of collagen and its hormonal control in the rat with special emphasis on the interaction of collagen and calcium in the bones. Acta Endocrinol. 1967, 120 (Suppl. S1967), S17-S86. [CrossRef]

16. Ribitsch, I.; Gueltekin, S.; Keith, M.F.; Minichmair, K.; Peham, C.; Jenner, F.; Egerbacher, M. Age-related changes of tendon fibril micro-morphology and gene expression. J. Anat. 2020, 236, 688-700. [CrossRef] [PubMed]

17. Jozsa, L.; Kannus, P. Human Tendons. Anatomy, Physiology, and Pathology. Champaign IL Hum. Kinet. 1997, $33,185$.

18. Green, E.M.; Mansfield, J.C.; Bell, J.S.; Winlove, C.P. The structure and micromechanics of elastic tissue. Interface Focus 2014, 4, 20130058. [CrossRef] [PubMed]

19. Godinho, M.S.C.; Thorpe, C.T.; Greenwald, S.E.; Screen, H.R.C. Elastin is Localised to the Interfascicular Matrix of Energy Storing Tendons and Becomes Increasingly Disorganised With Ageing. Sci. Rep. 2017, 7, 9713. [CrossRef]

20. Duchamp de Lageneste, O.; Julien, A.; Abou-Khalil, R.; Frangi, G.; Carvalho, C.; Cagnard, N.; Cordier, C.; Conway, S.J.; Colnot, C. Periosteum contains skeletal stem cells with high bone regenerative potential controlled by Periostin. Nat. Commun. $2018,9,773$. [CrossRef]

21. Norris, R.A.; Damon, B.; Mironov, V.; Kasyanov, V.; Ramamurthi, A.; Moreno-Rodriguez, R.; Trusk, T.; Potts, J.D.; Goodwin, R.L.; Davis, J.; et al. Periostin regulates collagen fibrillogenesis and the biomechanical properties of connective tissues. J. Cell Biochem. 2007, 101, 695-711. [CrossRef]

22. Wang, Y.; Jin, S.; Luo, D.; He, D.; Shi, C.; Zhu, L.; Guan, B.; Li, Z.; Zhang, T.; Zhou, Y.; et al. Functional regeneration and repair of tendons using biomimetic scaffolds loaded with recombinant periostin. Nat. Commun. 2021, 12, 1293. [CrossRef] [PubMed]

23. Dasheng, L.; Alberton, P.; Caceres, M.D.; Prein, C.; Clausen-Schaumann, H.; Dong, J.; Aszodi, A.; Shukunami, C.; Clatridis, J.; Docheva, D. Loss of tenomodulin expression is a risk factor for age-related intervertebral disc degeneration. Aging Cell 2020, 19, e13091.

24. Manning, C.N.; Kim, H.M.; Sakiyama-Elbert, S.; Galatz, L.M.; Havlioglu, N.; Thomopoulos, S. Sustained delivery of transforming growth factor beta three enhances tendon-to-bone healing in a rat model. J. Orthop. Res. 2011, 29, 1099-1105. [CrossRef] [PubMed]

25. Kaji, D.A.; Howell, K.L.; Balic, Z.; Hubmacher, D.; Huang, A.H. Tgf $\beta$ signaling is required for tenocyte recruitment and functional neonatal tendon regeneration. eLife 2020, 9, e51779. [CrossRef] [PubMed] 
26. Lejard, V.; Blais, F.; Guerquin, M.-J.; Bonnet, A.; Bonnin, M.-A.; Havis, E.; Malbouyres, M.; Bonod Bidaud, C.; Maro, G.; Pascale Gilardi-Hebenstreit, P.; et al. EGR1 and EGR2 involvement in vertebrate tendon differentiation. J. Biol. Chem. 2011, 286, 5855-5867. [CrossRef] [PubMed]

27. Tao, X.; Liu, J.; Chen, L.; Zhou, Y.; Tang, K. EGR1 induces tenogenic differentiation of tendon stem cells and promotes rabbit rotator cuff repair. Cell Physiol. Biochem. 2015, 35, 699-709. [CrossRef]

28. Guerquin, M.J.; Charvet, B.; Nourissat, G.; Havis, E.; Ronsin, O.; Bonnin, M.A.; Ruggiu, M.; Olivera-Martinez, I.; Robert, N.; Lu, Y.; et al. Transcription factor EGR1 directs tendon differentiation and promotes tendon repair. J. Clin. Investig. 2013, 123, 3564-3576. [CrossRef]

29. Kosaka, H.; Sairyo, K.; Biyani, A.; Leaman, D.; Yeasting, R.; Higashino, K.; Sakai, T.; Katoh, S.; Sano, T.; Goel, V.K.; et al. Pathomechanism of loss of elasticity and hypertrophy of lumbar ligamentum flavum in elderly patients with lumbar spinal canal stenosis. Spine 2007, 32, 2805-2811. [CrossRef]

30. Sindram, D.; Martin, K.; Meadows, J.P.; Prabhu, A.S.; Heath, J.J.; McKillop, I.H.; Iannitti, D.A. Collagen-elastin ratio predicts burst pressure of arterial seals created using a bipolar vessel sealing device in a porcine model. Surg. Endosc. 2011, 25, 2604-2612. [CrossRef]

31. Akturk, M.; Karaahmetoglu, S.; Kacar, M.; Muftuoglu, O. Thickness of the Supraspinatus and Biceps Tendons in Diabetic Patients Diabetes Care 2002, 25, 408. [CrossRef] [PubMed]

32. De Oliveira, R.R.; Martins, C.S.; Rocha, Y.R.; Braga, A.B.; Mattos, R.M.; Hecht, F.; Brito, G.A.; Nasciutti, L.E. Experimental diabetes induces structural, inflammatory and vascular changes of Achilles tendons. PLoS ONE 2013, 8, e74942.

33. Boivin, G.P.; Elenes, E.Y.; Schultze, A.K.; Chodavarapu, H.; Hunter, S.A.; Elased, K.M. Biomechanical properties and histology of $\mathrm{db} / \mathrm{db}$ diabetic mouse Achilles tendon. Muscles Ligaments Tendons J. 2014, 17, 280-284. [CrossRef]

34. Guney, A.; Vatansever, F.; Karaman, I.; Kafadar, I.H.; Oner, M.; Turk, C.Y. Biomechanical Properties of Achilles Tendon in Diabetic vs. Non-diabetic Patients. Exp. Clin. Endocrinol. Diabetes 2015, 123, 428-432. [CrossRef] [PubMed]

35. Kadler, K.E.; Hill, A.; Canty-Laird, E.G. Collagen fibrillogenesis: Fibronectin, integrins, and minor collagens as organizers and nucleators. Curr. Opin. Cell Biol. 2008, 20, 495-501. [CrossRef] [PubMed]

36. Ito, Y.; Toriuchi, N.; Yoshitaka, T.; Ueno-Kudoh, H.; Sato, T.; Yokoyama, S.; Nishida, K.; Akimoto, T.; Takahashi, M.; Miyaki, S.; et al. The Mohawk homeobox gene is a critical regulator of tendon differentiation. Proc. Natl. Acad. Sci. USA 2010, 107, 10538-10542. [CrossRef] [PubMed]

37. Murchison, N.D.; Price, B.A.; Conner, D.A.; Keene, D.R.; Olson, E.N.; Tabin, C.J.; Schweitzer, R. Regulation of tendon differentiation by scleraxis distinguishes force-transmitting tendons from muscle-anchoring tendons. Development 2007, 134, 2697-2708. [CrossRef] [PubMed]

38. Kessler, E.; Takahara, K.; Biniaminov, L.; Brusel, M.; Greenspan, D.S. Bone morphogenetic protein-1: The type I procollagen C-proteinase. Science 1996, 271, 360-362. [CrossRef]

39. Sharir, A.; Zelzer, E. Tendon homeostasis: The right pull. Curr. Biol. 2011, 21, R472-R474. [CrossRef]

40. Burner, T.; Gohr, C.; Mitton-Fitzgerald, E.; Rosenthal, A.K. Hyperglycemia reduces proteoglycan levels in tendons. Connect. Tissue Res. 2012, 53, 535-541. [CrossRef]

41. Robinson, K.A.; Sun, M.; Barnum, C.E.; Weiss, S.N.; Huegel, J.; Shetye, S.S.; Lin, L.; Saez, D.; Adams, S.M.; Iozzo, R.V.; et al Decorin and biglycan are necessary for maintaining collagen fibril structure, fiber realignment, and mechanical properties of mature tendons. Matrix Biol. 2017, 64, 81-93. [CrossRef] [PubMed]

42. Raspanti, M.; Congiu, T.; Guizzardi, S. Structural aspects of the extracellular matrix of the tendon: An atomic force and scanning electron microscopy study. Arch. Histol. Cytol. 2002, 65, 37-43. [CrossRef] [PubMed]

43. Zhang, G.; Ezura, Y.; Chervoneva, I.; Robinson, P.S.; Beason, D.P.; Carine, E.T.; Soslowsky, L.J.; Iozzo, R.V.; Birk, D.E. Decorin regulates assembly of collagen fibrils and acquisition of biomechanical properties during tendon development. J. Cell. Biochem. 2006, 98, 1436-1449. [CrossRef] [PubMed]

44. Eliasson, P.; Andersson, T.; Aspenberg, P. Rat Achilles tendon healing: Mechanical loading and gene expression. J. Appl. Physiol. 2009, 107, 399-407. [CrossRef] [PubMed]

45. Martin, J.A.; Mehr, D.; Pardubsky, P.D.; Buckwalter, J.A. The role of tenascin-C in adaptation of tendons to compressive loading. Biorheology 2003, 40, 321-329. [PubMed]

46. Bryzgalova, G.; Gao, H.; Ahren, B.; Zierath, J.R.; Galuska, D.; Steiler, T.L.; Dahlman-Wright, K.; Nilsson, S.; Gustafsson, J.A.; Efendic, S.; et al. Evidence that oestrogen receptor-alpha plays an important role in the regulation of glucose homeostasis in mice: Insulin sensitivity in the liver. Diabetologia 2006, 49, 588-597. [CrossRef] [PubMed]

47. Manrique, C.; Lastra, G.; Habibi, J.; Mugerfeld, I.; Garro, M.; Sowers, J.R. Loss of estrogen receptor $\alpha$ signaling leads to insulin resistance and obesity in young and adult female mice. Cardiorenal. Med. 2012, 2, 200-210. [CrossRef]

48. Ribas, V.; Nguyen, M.T.; Henstridge, D.C.; Nguyen, A.K.; Beaven, S.W.; Watt, M.J.; Hevener, A.L. Impaired oxidative metabolism and inflammation are associated with insulin resistance in ERalpha-deficient mice. Am. J. Physiol. Endocrinol. Metab. 2010, 298, E304-E319. [CrossRef]

49. Barros, R.P.; Gabbi, C.; Morani, A.; Warner, M.; Gustafsson, J.A. Participation of ERalpha and ERbeta in glucose homeostasis in skeletal muscle and white adipose tissue. Am. J. Physiol. Endocrinol. Metab. 2009, 297, E124-E133. [CrossRef]

50. Barros, R.P.; Machado, U.F.; Warner, M.; Gustafsson, J.A. Muscle GLUT4 regulation by estrogen receptors ERbeta and ERalpha. Proc. Natl. Acad. Sci. USA 2006, 103, 1605-1608, Erratum in Proc. Natl. Acad. Sci. USA 2006, 103, 8298-8299. [CrossRef] 
51. Ogawa, S.; Chan, J.; Gustafsson, J.A.; Korach, K.S.; Pfaff, D.W. Estrogen increases locomotor activity in mice through estrogen receptor alpha: Specificity for the type of activity. Endocrinology 2003, 144, 230-239. [CrossRef] [PubMed]

52. Gorres, B.K.; Bomhoff, G.L.; Morris, J.K.; Geiger, P.C. In vivo stimulation of oestrogen receptor $\alpha$ increases insulin-stimulated skeletal muscle glucose uptake. J. Physiol. 2011, 589, 2041-2054. [CrossRef]

53. Heine, P.A.; Taylor, J.A.; Iwamoto, G.A.; Lubahn, D.B.; Cooke, P.S. Increased adipose tissue in male and female estrogen receptor-alpha knockout mice. Proc. Natl. Acad. Sci. USA 2000, 97, 12729-12734. [CrossRef] [PubMed]

54. Hevener, A.L.; Clegg, D.J.; Mauvais-Jarvis, F. Impaired estrogen receptor action in the pathogenesis of the metabolic syndrome. Mol. Cell Endocrinol. 2015, 418, 306-321. [CrossRef] [PubMed]

55. Matic, M.; Bryzgalova, G.; Gao, H.; Antonson, P.; Humire, P.; Omoto, Y.; Portwood, N.; Pramfalk, C.; Efendic, S.; Berggren, P.O.; et al. Estrogen signalling and the metabolic syndrome: Targeting the hepatic estrogen receptor alpha action. PLoS ONE 2013, 8, e57458. [CrossRef]

56. Kinitz, R.; Heyne, E.; Koch, L.G.; Britton, S.L.; Thierbach, M.; Wildemann, B. The Effect of Age and Intrinsic Aerobic Exercise Capacity on the Expression of Inflammation and Remodeling Markers in Rat Achilles Tendons. Int. J. Mol. Sci. 2022, 23, 79. [CrossRef] 